\title{
Experimental and Theorical Study of the Air Quality in a Suburban Industrial-Residential Area in Rio de Janeiro, Brazil
}

\author{
Fernanda Rodrigues, ${ }^{a}$ Ivan Milas, ${ }^{a}$ Eduardo M. Martins, ${ }^{a}$ Graciela Arbilla, ${ }^{*, a}$ \\ Glauco F. Bauerfeldt ${ }^{b}$ and Murilo de Paula ${ }^{b}$ \\ ${ }^{a}$ Instituto de Química, Universidade Federal do Rio de Janeiro, CT Bloco A, Cidade Universitária, \\ Ilha do Fundão, 21949-900 Rio de Janeiro-RJ, Brazil \\ ${ }^{b}$ Analytical Solution, Rua Cubatão, 1088/1090, Vila Mariana, 04013-004 São Paulo-SP, Brazil
}

\begin{abstract}
Neste trabalho, dados de poluentes legislados e não legislados foram obtidos em uma região industrial-residencial no Rio de Janeiro, no período de abril a novembro de 2002. As concentrações de formaldeído e acetaldeído encontradas estavam na faixa de 25,25-231,73 ppb e 9,48-75,74 ppb respectivamente. Estas altas concentrações podem ser atribuídas a diversas fontes: emissões veiculares e industriais, a presença de incineradores de lixo, efluentes e rejeitos despejados no rio Faria Timbó e emissões de uma industria de metanol. As concentrações médias de BTEX foram: $1,92,9,02,6,37,21,65$ e 5,99 $\mu \mathrm{g} \mathrm{m}^{-3}$ para benzeno, tolueno, etilbenzeno, m,p-xileno e o-xileno, respectivamente. As concentrações médias de $\mathrm{PM}_{10}$ mostram valores máximos para o mês de outubro, abril e junho. As concentrações obtidas nas simulações foram para o mês de agosto usando um modelo de trajetórias. A concentração máxima de ozônio calculada foi de 39,8 ppb, as 15:00 horas, obtendo uma boa concordância com os dados experimentais (38,5 ppb). A isopleta de ozônio mostra que o local está em uma região alta de $\mathrm{VOC} / \mathrm{NO}_{\mathrm{x}}$, típica de áreas suburbanas e a favor do vento.
\end{abstract}

In this work, data for criteria and non-criteria pollutants were obtained in a suburban industrial-residential area in Rio de Janeiro, from April to November 2002. Formaldehyde and acetaldehyde concentrations were found in the ranges $25.25-231.73 \mathrm{ppb}$ and $9.48-75.74 \mathrm{ppb}$, respectively. These high concentrations may be attributed to several sources: vehicular and industrial emissions, the presence of several trash incinerators, effluents and waste rejected in the Faria Timbó river and emissions from a methanol industry. Average BTEX concentrations were: $1.92,9.02,6.37,21.65$ and $5.99 \mu \mathrm{g} \mathrm{m}^{-3}$ for benzene, toluene, ethylbenzene, $m, p$-xylene and $o$-xylene, respectively. $\mathrm{PM}_{10}$ concentrations showed maximum mean values in October, April and June. Simulated concentrations were obtained for August 2002 using a trajectory model. The maximum calculated ozone concentration was $39.8 \mathrm{ppb}$, at 3:00 pm, in good agreement with experimental data $(38.5 \mathrm{ppb})$. The ozone isopleths show that the local is in the high $\mathrm{VOC} / \mathrm{NO}_{\mathrm{x}}$ region, typical of suburban and downwind areas.

Keywords: atmospheric pollution, air quality simulation, aldehydes, BTEX

\section{Introduction}

In recent years, the environmental and atmospheric chemistry have been drawing an increasing amount of attention. The study of urban atmosphere involves the attainment of experimental data through monitoring campaigns, air quality simulations, and measurements and evaluation of kinetic constants of main atmospheric reactions. ${ }^{1}$

*e-mail: graciela@iq.ufrj.br
A big challenge in the study of the urban atmospheric chemistry is the correlation of air quality with sources of emissions and meteorological factors, the determination of concentrations of primary and secondary pollutants and the simulation of air quality by photochemical models.

The latest inventory of pollutants of the metropolitan area of Rio de Janeiro compiled by the State Foundation of Environmental Engineering (FEEMA) shows that the contribution of automotive vehicles in total pollutant emissions is around $77 \%$. However, the contribution profile of each pollutant can vary significantly. For 
example, $98 \%$ of the carbon monoxide comes from traffic ways, but most of the sulphur dioxide $(88 \%)$ is emitted directly from industrial sources. Nitrogen oxides and hydrocarbons are also originated from combustion of fossil fuels, with $60 \%$ coming from moving sources. As far as particulate matter is concerned the contribution of fixed and moving sources is similar, with an important role played by automotive vehicles. ${ }^{2}$

In the 80's and 90's, the use of alcohol as a fuel and additive to gasoline has led to a decrease in $\mathrm{CO}$ and volatile organic compounds (VOC) emissions and an increase of acetaldehyde emissions. As a result the acetaldehyde/ formaldehyde concentration ratio at that time was usually greater than $1.0 .^{3,4}$

Recently, the number of alcohol-propelled vehicles has dropped considerably, while the use of natural gas as fuel has significantly increased. These changes in the profile of the fleet are reflected in the composition of emissions and in the concentrations of primary and secondary pollutants. In particular, in the last two years an increase of the formaldehyde concentrations was observed, while the acetaldehyde concentrations remained approximately constant. ${ }^{5,6}$

A number of monitoring campaigns have been undertaken in regions of high vehicular traffic density in the city of Rio de Janeiro, in particular at Presidente Vargas Avenue, the largest artery in downtown, in the period 19982003 and in the commercial-residential area of Saens Peña Square (Tijuca) in the period 2002-2003. - $^{-9}$

This work differs from the previous monitoring campaigns in Presidente Vargas Avenue and Tijuca, in two main aspects. First, it involves an integrated study of experimental data of criteria and non-criteria pollutants and an interpretation of these data by means of the results of an air quality model. Moreover, the location of the study area distant from the city's downtown. In this region the concentration of ozone, in the situation where the $[\mathrm{VOC}] /\left[\mathrm{NO}_{\mathrm{x}}\right]$ ratio is relatively high may be analyzed.

The sampling campaign was carried out in collaboration with technicians of the Air Quality Division of the Municipal Environmental Office of the city of Rio de Janeiro (SMAC). The meteorological data and the concentrations of the following legislated pollutants were obtained from SMAC's Automatic Mobile Monitoring Station: carbon monoxide, nitrogen oxide, ozone, methane, non-methane hydrocarbons, total hydrocarbons, sulphur dioxide and particulate matter. ${ }^{10}$ The measurements of the concentrations of formaldehyde, acetaldehyde and volatile aromatic compounds (BTEX: benzene, toluene, ethylbenzene, $m, p$-xylene and $o$-xylene) were performed by our research group. After the statistical treatment of data, a simulation of air quality was performed using the SAPRC chemical model and the OZIPR air quality atmospheric model. ${ }^{11-13}$

\section{Methodology}

\section{Location and time of sampling}

The metropolitan region of Rio de Janeiro (RMRJ) is one of the most densely populated regions in the country with approximately 1900 habitants $\mathrm{km}^{-2}$. It comprises 19 municipalities, occupies an area of $6500 \mathrm{~km}^{2}$, which is $4.9 \%$ of the state total area and has a total population of eleven million, $60 \%$ of which live in the municipality of Rio de Janeiro.

The metropolitan region has the country's second largest concentrations of industries and vehicles. The region's hilly topography, the presence of the Tijuca Massive and the Guanabara Bay, along with the tropical climate that favors photochemical processes and other reactions in the atmosphere that intensify air quality problems.

Based on the landscape, the soil covering and climatological characteristics, the region can be divided into four basins. The Basin III is comprised of the north zone of the municipality of Rio de Janeiro and the northern suburbs of the city, encompassing an area of $140 \mathrm{~km}^{2}$. This region is the most critical one from the air quality standpoint when considering particulate matter and ozone levels.

The location studied in the this work was the Manguinhos Campus of FIOCRUZ, which is approximately 300 meters from the Leopoldo Bulhões Avenue, in the neighborhood of Bonsucesso, in Basin III.

In this location, away from the city's downtown area, the emissions originate from vehicular traffic (light vehicles, buses and trucks) and from some local industrial plants. The channel of the Faria Timbó river, which receives effluents and waste from industries and residences, flows at approximately 200 meters from the sampling location. The location and the neighboring regions (Bonsucesso, Manguinhos and Benfica) are home to approximately 100 industrial yards, in particular, 8 graphic services and 16 metallurgical plants.

In addition, Rio de Janeiro's largest methanol factory, with a production of 450 ton day ${ }^{-1}$, is approximately $1 \mathrm{~km}$ away from the location. Moreover, several warehouses of various materials are present in the area, causing intensive truck traffic. 
The samples of aldehydes and BTEX were collected between the months of April and December of 2002, from 9:00 am to 3:00 pm. The sampling days were: April 15 and 16, June 5 and 6; July 16 and 19; August 15 and 16; September 3, 5 and 6; October 7, 8, and 9; November 11. A total of 45 aldehyde and 13 BTEX samples were collected. The activities of the Mobile Monitoring Station were checked during that time period.

\section{Aldehydes sampling and analysis}

In this work, the determination of aldehydes was done using US-EPA TO-11A method, which was described in details in previous works. ${ }^{6,8,14}$ In this method, a flux of air is run through the cartridge that contains a support phase of resin C18 coated with 2,4dinitrophenylhydrazine (DNPH). The hydrazine, in contact with carbonylic groups from the atmosphere, is converted to the corresponding hydrazone. The compounds are, then, eluted with acetonitrile, collected in $5 \mathrm{~mL}$ volumetric flask, stored in vials and analyzed by High Performance Liquid Chromatography (HPLC).

The sampling system contains an autonomous sampling air pump (SKC) operating on batteries; a cartridge of C18 coated with DNPH, an ozone trap and silicon tubes used for connections. The samples were collected during a twohour period at a flow rate of $1 \mathrm{~L} \mathrm{~min}^{-1}$.

The samples were analyzed using a Perkin Elmer Series 200 HPLC, with a Nova Pak C18 column (3.9 mm $\times$ $150 \mathrm{~mm}$ and particle size of $4 \mu \mathrm{m}$ ) and a Perkin Elmer Series $200 \mathrm{UV}$-Vis detector at $365 \mathrm{~nm}$. An aliquot of 100 $\mu \mathrm{L}$ was injected with a sampling loop of $20 \mu \mathrm{L}$. A $55 \%$ acetonitrile $/ 45 \%$ water mobile phase was used.

The quantification of the samples was done using five Supelco standards (CARB-DNPH Mix 1) with concentrations of: $1.961 ; 3.846 ; 5.660 ; 7.407 ; 9.091$ $\mu \mathrm{g} \mathrm{mL} \mathrm{m}^{-1}$ that were analyzed at the same conditions as the samples. The correlation coefficient of the calibration curves was 0.999 for formaldehyde and acetaldehyde, while for higher molecular weight aldehydes the correlation coefficient varied between 0.997 and 0.965 . In order to guarantee the absence of external contamination control procedures (blanks) were performed. In all cases, the concentrations obtained with blanks were lower than $10 \%$ of the concentrations in the samples.

\section{BTEX sampling and analysis}

BTEX were sampled and analyzed using a methodology based on EPA methods. ${ }^{15,16}$ BTEX were sampled by drawing air through tubes $7 \mathrm{~cm}$ long, $4 \mathrm{~mm}$ ID, containing 2 sections of activated coconut shell charcoal (main section $100 \mathrm{mg}$, second section $50 \mathrm{mg}$ ) separated by a $2 \mathrm{~mm}$ urethane foam (SKC), during 6 hours, at a flow rate of $1.0 \mathrm{~L} \mathrm{~min}^{-1}$. The second section of tube was analyzed in order to detect breakthroughs.

Charcoal beds in the sorbent tubes were transferred to $2 \mathrm{~mL}$ vials and extracted by adding $1.0 \mathrm{~mL}$ of $\mathrm{CH}_{2} \mathrm{Cl}_{2}$ with occasional agitation for 30 minutes. Bromofluorbenzene was added prior to extraction as internal standard. The samples were analyzed using a Trace GC coupled to a DSQ Quadrupole Mass Spectrometer (Thermo Finnigan). The column used was a DB-5 (5\% phenyl-methyl-siloxane) J\&W Scientifics, 60 meters long with $0.25 \mathrm{~mm}$ internal diameter and $0.25 \mu \mathrm{m}$

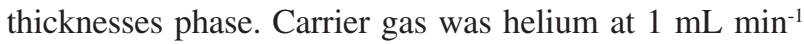
and $25 \mathrm{~cm} \mathrm{~s}^{-1}$ linear velocity. The injection mode was splitless with inlet temperature of $250{ }^{\circ} \mathrm{C}$. Temperature program was: $45^{\circ} \mathrm{C}$, hold 2 minutes, $45-200{ }^{\circ} \mathrm{C}$ at $6{ }^{\circ} \mathrm{C}$ $\mathrm{min}^{-1}$, hold for 5 minutes. Mass spectrometer ionization was by electron impact and ion source, quadrupole and $\mathrm{GC} / \mathrm{MS}$ interface temperatures were $230^{\circ} \mathrm{C}, 150^{\circ} \mathrm{C}$ and $250{ }^{\circ} \mathrm{C}$, respectively.

The MS was run in selective ion monitoring mode. For each compound, two ions (one target and one qualifier) were monitored. Compounds were identified based on their relative retention times and ion ratios. Identified compounds were quantified using an internal calibration procedure, with five levels of calibration as follows: 0.1 ; $1 ; 5 ; 25 ; 100 \mu \mathrm{g} \mathrm{mL} \mathrm{mL}^{-1}$ in $\mathrm{CH}_{2} \mathrm{Cl}_{2}$, with $1 \mu \mathrm{g} \mathrm{mL} \mathrm{m}^{-1}$ of bromofluorbenzene in all solutions. All calibration solutions were purchased from Supelco. Correlation coefficient was evaluated and 0.99 was considered acceptable.

\section{Determination of criteria pollutants and meteorological parameters}

The data from SMAC's air quality Mobile Automatic Monitoring Station were obtained in intervals of one minute and were averaged over one-hour periods. Concentrations of $\mathrm{CO}, \mathrm{NO}_{\mathrm{x}}, \mathrm{O}_{3}, \mathrm{CH}_{4}, \mathrm{SO}_{2}, \mathrm{HCNM}$ (non methanic hydrocarbons) and $\mathrm{PM}_{10}$ were measured, as well as, temperature, air humidity, atmospheric pressure and the solar radiation index.

\section{Air quality simulation}

The chemical and physical transformations in urban and rural atmospheres can be simulated using atmospheric models of different complexity. For this case, in which 
the meteorological data, the initial concentrations (in the early morning), and the emission data are scarce, it is more appropriate to use simplified models like OZIPR ${ }^{17}$

The OZIPR software simulates chemical and physical processes that occur in the low atmosphere using a trajectories model. The physical representation is an air column that goes from the ground to the maximum height of the boundary layer. This ideal air column runs with the wind along a trajectory, but it does not expand horizontally. The OZIPR model is usually used for simulations of the daylight period and for a single simulation day.

The data necessary for the input file, which characterize the initial and boundary condition of a simulation are: initial concentrations and hourly emission values of primary pollutants (VOC, $\mathrm{NO}_{\mathrm{x}}$ and $\mathrm{CO}$ ), meteorological data throughout the day, geographical localization, deposition coefficients for each of the chemical compounds and speciated hydrocarbons concentrations.

The initial concentration (08:00 am) used in the simulation were 0.70 and $0.03 \mathrm{ppm}$ for $\mathrm{CO}$ and $\mathrm{NO}_{\mathrm{x}}$, respectively, the mean experimental values obtained by the automatic monitoring station for August 2002. The VOC initial concentration was set as $0.5 \mathrm{ppmC}$, following TO-14A US-EPA results. ${ }^{7}$ Experimental meteorological input parameters, for the same period, as well as estimated mixing heights are presented in Table 1.

Table 1. Input data for the simulation of the air quality, in August 2002, at FIOCRUZ Campus

\begin{tabular}{lccc}
\hline Day Time & Temperature $/{ }^{\circ} \mathrm{C}$ & Humidity/(\%) & Mixing Height $/ \mathrm{m}$ \\
\hline 8:00 am & 23.49 & 77.31 & 700 \\
09:00 am & 25.05 & 68.31 & 900 \\
10:00 am & 28.27 & 62.07 & 1300 \\
11:00 am & 27.76 & 56.48 & 1600 \\
12:00 am & 28.73 & 52.76 & 1800 \\
01:00 pm & 29.32 & 49.65 & 2000 \\
02:00 pm & 28.53 & 49.50 & 1800 \\
03:00 pm & 31.13 & 51.78 & 1600 \\
04:00 pm & 27.98 & 56.72 & 1100 \\
05:00 pm & 26.05 & 63.62 & 1000 \\
06:00 pm & 24.65 & 69.58 & 900 \\
07:00 pm & 24.13 & 72.62 & 700 \\
\hline
\end{tabular}

The initial and maximum mixing heights were set as $700 \mathrm{~m}$ and $2000 \mathrm{~m}$, respectively. The initial value was set according to the information of atmospheric temperature and pressure profiles available at the IAG-USP home page. ${ }^{18}$ Diurnal variations and final values were used as adjustable parameters, since there were no available experimental data. The main effect of the mixing height is the dilution of gases. ${ }^{12}$ Since, in this work, the absolute values of $\mathrm{CO}$ emissions were also used as adjustable parameters, an error in the mixing height may be corrected by changing the emissions.

The $\mathrm{VOC} / \mathrm{NO}_{\mathrm{x}} / \mathrm{CO}$ emission ratios were calculated in consistence with the vehicle emission inventory for the city of Rio de Janeiro and the FEEMA emission inventory for the Metropolitan Region of Rio de Janeiro. ${ }^{2,19}$ On a mass basis, the values 0.173 and 0.157 for the $\mathrm{VOC} / \mathrm{CO}$ and $\mathrm{NO}_{\mathrm{x}} / \mathrm{CO}$ ratios, respectively, were used. These ratios were kept constant during the simulation and, since they depend on the characteristics of the vehicular fleet, were considered as non-adjustable parameters. Absolute emission rates were adjusted to fit $\mathrm{CO}$ measured ambient concentrations (the average hourly values for the month of August 2002).

The chemical processes were described using the SAPRC model developed by Dr. W.P.L. Carter from the University of California-Riverside. ${ }^{20}$ This model was extensively used in our previous works. ${ }^{8,12,13}$ The mechanism details are described in those publications.

The organic compounds were grouped using the reactivity with the $\mathrm{OH}$ radical as criteria. In this way 14 different groups were obtained. The average concentration of each compound was determined using experimental data obtained by Corrêa at FIOCRUZ Campus using the TO-14 U.S-EPA method. ${ }^{7}$ The rate and stechiometric coefficients were calculated as weighted averages among all the components within a group of species. The description of the groups is shown in Table 2, along with the fractions associated with each one of them.

Table 2. Description of VOC groups for the air quality simulation

\begin{tabular}{lcc}
\hline Group & Description of group & Fraction \\
\hline ALK4 & Alkanes $<$ C4 & 0.340 \\
ALK7 & Alkanes $>$ C4 & 0.054 \\
ETHE & Ethene & 0.004 \\
PREP & Propene & 0.005 \\
TBUT & Alkenes $>$ C4 & 0.038 \\
TOLU & Toluene and Ethylbenzene & 0.100 \\
XYLE & Xylenes & 0.127 \\
TMBZ & Trimethylbenzenes & 0.069 \\
RCHO & Aldehydes $>$ C3 & 0.023 \\
BDIE & 1,3 Butadiene & 0.000 \\
HCHO & Formaldehyde & 0.110 \\
ALD2 & Acetaldehyde & 0.075 \\
NRCH & Non-reactives & 0.022 \\
ACRO & Acrolein & 0.000 \\
ETOH & Ethanol & 0.033 \\
\hline
\end{tabular}

A more detailed description of the physical and chemical model is given in Arbilla et al. ${ }^{12}$ and, for this reason, is not given here. 


\section{Results and Discussion}

\section{Experimental results}

Table 3 shows aldehyde concentrations, as determined in the period from April 2002 to November 2002. A total of 45 aldehyde samples were collected.

From a general standpoint, when compared to values reported by De Andrade et al. ${ }^{22}$ for Brazilian cities, concentrations of both compounds are larger. This increase of aldehydes concentration was already observed for the President Vargas Avenue in 1999-2003 and was attributed to a larger vehicular flux and the change in the profile of the fleet. The high concentrations obtained for formaldehyde may be due to different factors as: change in the profile of the vehicular fleet, especially, to the increase in the number of natural gas propelled vehicles; industrial emissions and the decomposition of organic

Table 3. Experimental aldehyde concentrations, in ppb units, for FIOCRUZ Campus, April-November 2002. N.A.: not analyzed; N.D.: not detected

\begin{tabular}{|c|c|c|c|c|c|c|}
\hline Date & Day Time & formaldehyde & acetaldehyde & propanaldehyde & butanaldehyde & crotonaldehyde \\
\hline \multirow{3}{*}{$04 / 15 / 02$} & 9:00 am-11:00 am & 98.41 & 14.30 & N.A. & N.A. & N.A. \\
\hline & 11:00 am-01:00 pm & 94.84 & 22.83 & N.A. & N.A. & N.A. \\
\hline & 01:00 pm-03:00 pm & 123.84 & 50.83 & N.A. & N.A. & N.A. \\
\hline \multirow{3}{*}{$04 / 16 / 02$} & 9:00 am-11:00 am & 119.57 & 21.63 & N.A. & N.A. & N.A. \\
\hline & 11:00 am-01:00 pm & 62.66 & 14.23 & N.A. & N.A. & N.A. \\
\hline & 01:00 pm-03:00 pm & 117.02 & 27.02 & N.A. & N.A. & N.A. \\
\hline \multirow{3}{*}{$06 / 05 / / 02$} & 9:00 am-11:00 am & 157.79 & 28.26 & N.A. & N.A. & N.A. \\
\hline & 11:00 am-01:00 pm & N.D. & N.D. & 2.65 & N.D. & 1.11 \\
\hline & 01:00 pm-03:00 pm & 180.61 & 28.13 & N.D. & N.D. & N.D. \\
\hline \multirow{3}{*}{ 06/06/02 } & 9:00 am-11:00 am & 179.58 & 44.90 & 2.37 & 1.47 & 1.08 \\
\hline & 11:00 am-01:00 pm & 200.57 & 39.60 & 3.55 & N.D. & 1.54 \\
\hline & 01:00 pm-03:00 pm & 179.06 & 28.98 & 2.22 & N.D. & 1.55 \\
\hline \multirow{3}{*}{ 07/16/02 } & 9:00 am-11:00 am & 131.77 & 21.97 & N.D. & N.D. & N.D. \\
\hline & 11:00 am-01:00 pm & 162.43 & 31.21 & 1.72 & N.D. & 0.69 \\
\hline & 01:00 pm-03:00 pm & 201.67 & 34.44 & 2.68 & N.D. & 2.14 \\
\hline \multirow{3}{*}{$07 / 19 / 02$} & 9:00 am-11:00 am & 79.01 & 18.72 & 2.64 & N.D. & 0.82 \\
\hline & 11:00 am-01:00 pm & 67.05 & 24.75 & 1.61 & N.D. & N.D. \\
\hline & 01:00 pm-03:00 pm & 65.50 & 25.67 & 1.68 & N.D. & N.D. \\
\hline \multirow{3}{*}{ 08/15/02 } & 9:00 am-11:00 am & N.D. & N.D. & 1.35 & N.D. & N.D. \\
\hline & 11:00 am-01:00 pm & 69.48 & 16.70 & N.D. & N.D. & N.D. \\
\hline & 01:00 pm-03:00 pm & 144.08 & 24.18 & 1.23 & N.D. & 1.27 \\
\hline \multirow{3}{*}{ 08/16/02 } & 9:00 am-11:00 am & 79.37 & 30.88 & 1.50 & N.D. & 3.46 \\
\hline & 11:00 am-01:00 pm & 80.15 & 34.71 & N.D. & 1.01 & N.D. \\
\hline & 01:00 pm-03:00 pm & 122.93 & 27.73 & 2.23 & N.D. & N.D. \\
\hline \multirow{3}{*}{ 09/03/02 } & 9:00 am-11:00 am & 97.63 & 33.12 & N.D. & N.D. & N.D. \\
\hline & 11:00 am-01:00 pm & 75.85 & 37.73 & N.D. & 1.83 & N.D. \\
\hline & 01:00 pm-03:00 pm & 93.68 & 33.35 & N.D. & 1.39 & N.D. \\
\hline \multirow{3}{*}{ 09/05/02 } & 9:00 am-11:00 am & 174.62 & 32.58 & N.D. & 2.39 & N.D. \\
\hline & 11:00 am-01:00 pm & 169.59 & 35.33 & N.D. & 1.17 & N.D. \\
\hline & 01:00 pm-03:00 pm & 147.14 & 33.68 & N.D. & 1.68 & N.D. \\
\hline \multirow{3}{*}{ 09/06/02 } & 9:00 am-11:00 am & 133.59 & 36.62 & 2.30 & 1.95 & 2.82 \\
\hline & 11:00 am-01:00 pm & 132.69 & 36.75 & 2.23 & 2.12 & 0.48 \\
\hline & 01:00 pm-03:00 pm & 163.59 & 37.61 & 1.66 & 1.86 & N.D. \\
\hline \multirow{3}{*}{$10 / 07 / 02$} & 9:00 am-11:00 am & 168.60 & 48.87 & 1.65 & 1.61 & N.D. \\
\hline & 11:00 am-01:00 pm & 145.66 & 62.39 & 3.16 & N.D. & N.D. \\
\hline & 01:00 pm-03:00 pm & 219.21 & 61.79 & 2.76 & 4.87 & 1.36 \\
\hline \multirow{3}{*}{$10 / 08 / 02$} & 9:00 am-11:00 am & 155.71 & 65.58 & 3.20 & N.D. & N.D. \\
\hline & 11:00 am-01:00 pm & 137.38 & 57.74 & 3.93 & 2.42 & N.D. \\
\hline & 01:00 pm-03:00 pm & 201.80 & 61.13 & 3.16 & 1.67 & N.D. \\
\hline \multirow{3}{*}{$10 / 09 / 02$} & 9:00 am-11:00 am & 167.80 & 44.54 & 4.04 & N.D. & N.D. \\
\hline & 11:00 am-01:00 pm & 211.22 & 69.81 & 3.28 & N.D. & N.D. \\
\hline & 01:00 pm-03:00 pm & 231.72 & 75.74 & 3.57 & N.D. & 0.68 \\
\hline \multirow{3}{*}{$11 / 11 / 02$} & 9:00 am-11:00 am & 25.25 & 9.48 & N.D. & 5.68 & 0.48 \\
\hline & 11:00 am-01:00 pm & 43.61 & 15.59 & 0.75 & N.D. & N.D. \\
\hline & 01:00 pm-03:00 pm & 52.24 & 17.54 & 0.88 & N.D. & N.D. \\
\hline
\end{tabular}


compounds emitted from other sources, as for example, the channel of the Faria Timbó river; the presence of several trash incinerators and a methanol factory in the vicinity of the sampling location. ${ }^{5,13}$ Another possible source of formaldehyde is the high flux of diesel vehicles, mainly trucks, in Leopoldo Bulhões street, next to the sampling local. A mean formaldehyde/acetaldehyde ratio of 1.7 was obtained by De Andrade et al. ${ }^{21}$ for a commercial area in Salvador, Brazil, in which the predominant traffic is diesel-fueled buses.

In this work, the formaldehyde/acetaldehyde ratio displays values larger than 1.00 in all cases. This behavior was already observed in other studied locations in the city of Rio de Janeiro in the last five years. This fact has been largely discussed in recent papers. ${ }^{5,6}$ Briefly, Corrêa and Arbilla $^{5}$ reported that the formaldehyde/acetaldehyde ratio increased from 1.0 to 4.5 for the period 1998-2002. In 1999, ratios in the range 0.71-2.16 were obtained in São Paulo. ${ }^{22}$

The formaldehyde/acetaldehyde ratio obtained in this work is also in good agreement with reported values for Japan, 7.2, ${ }^{23}$ and New Mexico, 1.3-7.3. ${ }^{24}$ Also a mean ratio of 3.03 was measured for 350 samples obtained in European cities. ${ }^{25}$ De Andrade et al. ${ }^{22}$ compiled data for several urban areas in USA. Values between 0.30, in Perris, Los Angeles, CA and 32.25, in Lenox, CA have been reported.

The concentrations of formaldehyde are in the range of 25.25-231.73 ppb. The average value for all data is $131.76 \mathrm{ppb}$, while daily average values are in the range of 40.36-203.58 ppb. These values are much larger than those obtained at Presidente Vargas Avenue in the above mentioned period (1.52-54.31 ppb). ${ }^{7}$ Concentrations are similar to these obtained in Tijuca, where the average was $151.47 \mathrm{ppb}$ and the range $14.30-431.58 \mathrm{ppb} .^{6,9}$

Acetaldehyde concentrations are in the range of 9.48$75.74 \mathrm{ppb}$. The average value for all measurements is 35.31 ppb. Daily average values are in the range of 22.70-61.23 ppb. These values are slightly higher than those obtained at Presidente Vargas Avenue, a high traffic avenue in Rio de Janeiro, for the period December 1998 to January 2001 (2.36-45.60 ppb, Corrêa ${ }^{7}$ ) and in Tijuca District, Rio de Janeiro, for the period April 2002 to February 2003 (4.09$103.26 \mathrm{ppb}$ ). The average value, for the period, in Tijuca was 29.78 ppb. ${ }^{9}$

The propanaldehyde, butanaldehyde and crotonaldehyde concentrations are in the range 0.75-4.04, 1.015.68 and 0.48-3.46 ppb, respectively. Pentanaldehyde was not detected in this work. Similar values were obtained by Martins ${ }^{9}$ in Tijuca, Rio de Janeiro for propanaldehyde and butanaldehyde with values in the range 0.92-9.56 and 1.29-10.44 ppb respectively. Data for propanaldehyde were previously reported in Rio de Janeiro, with values between 0.2 and $3.0 \mathrm{ppb}^{26}$

The propanaldehyde concentrations, obtained in this work, are also similar to values obtained in Osaka, Japan, in the range $0.8-5.9 \mathrm{ppb}^{27}$ and the mean concentration for Claremont, USA, of 6.8 ppb. ${ }^{28}$ For butanaldehyde a mean value of $1.8 \mathrm{ppb}$ was reported for Claremont. ${ }^{28}$

The measured BTEX concentrations are shown in Table 4. 13 samples were collected. Benzene, toluene, ethylbenzene, $p, m$-xylene and $o$-xylene concentrations are in the ranges $0.28-3.13,4.73-13.56,2.93-10.56,10.05-$ 40.56 and $2.17-10.20 \mu \mathrm{g} \mathrm{m}^{-3}$, respectively. Mean values of $1.92,9.02,6.37,21.65$ and $5.99 \mu \mathrm{g} \mathrm{m}^{-3}$ were obtained for benzene, toluene, ethylbenzene, $m, p$-xylene and $o$-xylene, respectively.

Table 4. Experimental BTEX concentrations, in $\mu \mathrm{g} \mathrm{m}^{-3}$ units, for FIOCRUZ Campus, April-November 2002

\begin{tabular}{lccccc}
\hline Date & benzene & toluene & ethylbenzene & $m . p$-xylene & $o$-xylene \\
\hline $04 / 16 / 2002$ & 0.28 & 10.86 & 8.03 & 40.56 & 5.69 \\
$05 / 14 / 2002$ & 1.93 & 7.22 & 2.93 & 10.05 & 2.17 \\
$05 / 16 / 2002$ & 2.14 & 9.64 & 3.37 & 11.14 & 2.22 \\
$05 / 17 / 2002$ & 2.21 & 12.81 & 4.09 & 17.05 & 3.88 \\
$06 / 06 / 2002$ & 2.55 & 9.32 & 5.32 & 26.48 & 8.34 \\
$07 / 16 / 2002$ & 1.72 & 6.31 & 3.89 & 12.15 & 2.26 \\
$08 / 10 / 2002$ & 2.41 & 10.57 & 9.35 & 29.75 & 8.84 \\
$08 / 13 / 2002$ & 3.13 & 13.56 & 8.65 & 21.93 & 6.26 \\
$08 / 15 / 2002$ & 2.23 & 9.11 & 5.58 & 16.87 & 4.72 \\
$09 / 03 / 2002$ & 1.84 & 8.92 & 10.56 & 33.88 & 9.81 \\
$09 / 06 / 2002$ & 1.52 & 7.30 & 9.70 & 21.10 & 10.20 \\
$10 / 09 / 2002$ & 1.96 & 6.97 & 4.20 & 18.89 & 6.70 \\
$11 / 11 / 2002$ & 1.10 & 4.73 & 7.18 & 21.63 & 6.79 \\
\hline
\end{tabular}

When compared with recent data for Presidente Vargas Avenue, ${ }^{7}$ the average concentrations obtained in this work are lower than those measured in downtown $(9.4,17.0$, 12.7, 27.2 and $19.2 \mu \mathrm{g} \mathrm{m}^{-3}$ for benzene, toluene, ethylbenzene, $m, p$-xylene and $o$-xylene, respectively). For Tijuca, Rio de Janeiro, mean values of 1.13, 4.80, 3.61,

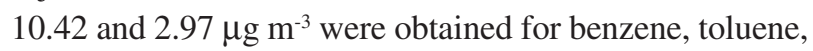
ethylbenzene, $m, p$-xylene and $o$-xylene, respectively, in the period March 2002 to February 2003. ${ }^{6}$ Benzene/ toluene ratios are nearly equal, for Fiocruz and Tijuca sampling locals (0.2), and are lower than the value for Presidente Vargas Avenue (0.55). All this data suggest that the main emission source of BTEX in the sampling local is the vehicular flux.

Figure 1 displays the average hourly values for concentrations of $\mathrm{CO}, \mathrm{PM}_{10}, \mathrm{NO}_{\mathrm{x}}$ and $\mathrm{O}_{3}$ for the months of April through December of 2002. The only pollutant that presented violations to the air quality standards was $\mathrm{PM}_{10}$.

The concentrations of $\mathrm{CO}$ show a maximum in the early morning and in the late afternoon, which are the 
a) 0.90

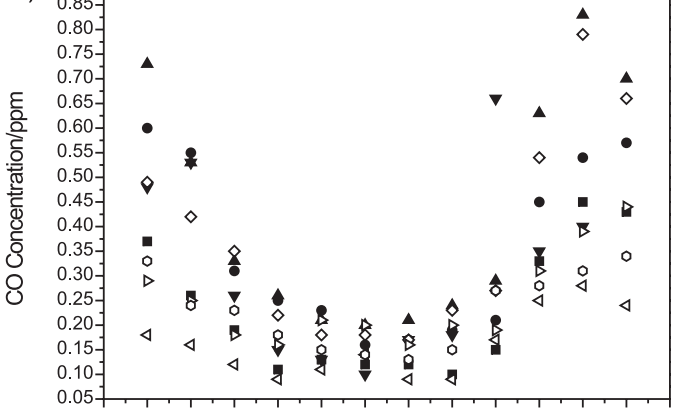

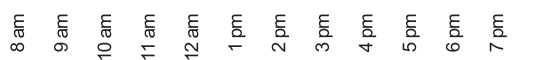

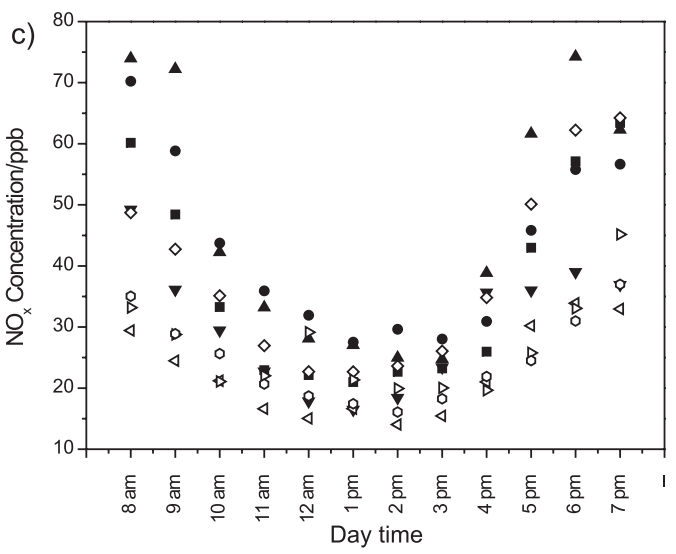

b)
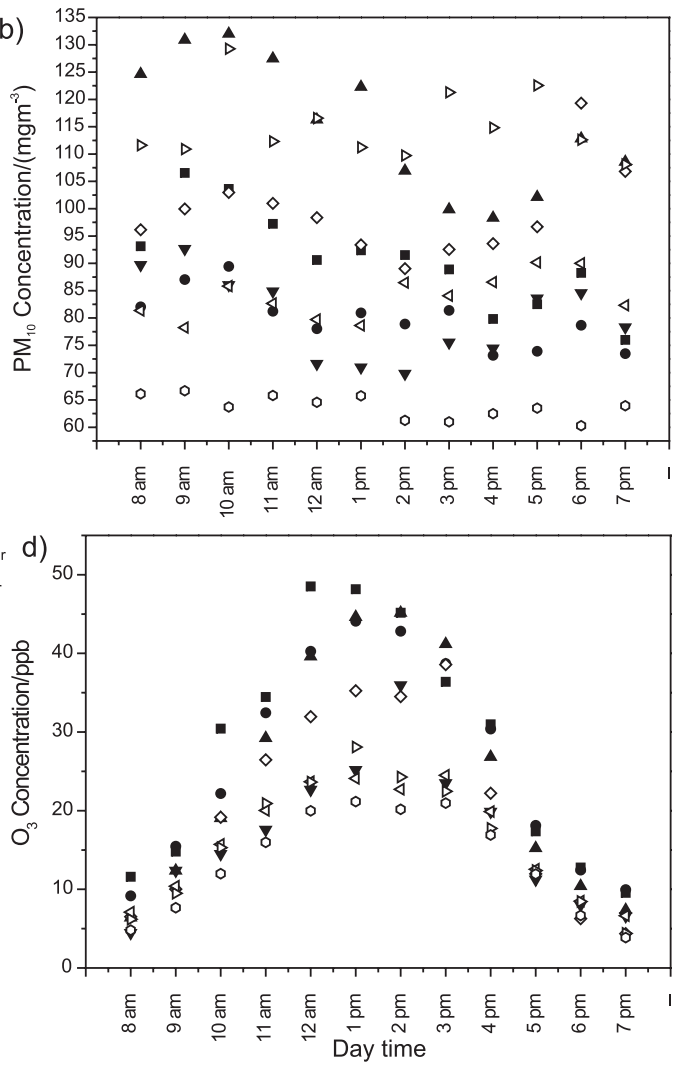

Figure 1. Hourly CO (1a), $\mathrm{PM}_{10}(1 \mathrm{~b}), \mathrm{NO}_{\mathrm{x}}(1 \mathrm{c})$ and $\mathrm{O}_{3}(1 \mathrm{~d})$ from April to November 2002, obtained by the Automatic Mobile Monitoring Station at FIOCRUZ Campus.

times of the day with higher vehicular fluxes. Mean values at 8:00 am and 6:00 pm are quite similar and about three times the values at midday. As expected, the values are larger in the autumn-winter months (May-August), which are characterized by more adverse climatic conditions.

The $\mathrm{PM}_{10}$ concentrations do not display a definite hourly profile, which suggests the possibility of having other sources of emissions besides the vehicles. A seasonal dependence is not observed with maximum monthly mean values for April (106.4 $\left.\mu \mathrm{g} \mathrm{m}^{-3}\right)$, June (132.20 $\mathrm{g} \mathrm{m}^{-3}$ ) and October (129.15 $\left.\mathrm{g} \mathrm{m} \mathrm{m}^{-3}\right)$. For comparison, the national primary and secondary air quality standards are: $150 \mu \mathrm{g} \mathrm{m}^{-3}$ for 24 hours and $50 \mu \mathrm{g}$ $\mathrm{m}^{-3}$ for annual geometrical mean. ${ }^{29}$ The reported values are not 24 hours or annual geometrical means, anyway they show that the air quality of the area, when considering particulate matter is not good.

NOx concentrations show a similar hourly distribution than $\mathrm{CO}$, since they are both primary pollutants. Also, the values are larger in the autumn-winter months (May-August), which are characterized by more adverse climatic conditions. The maximum values measured in this work are about 75 $\mathrm{ppb}$, which are much lower than the $\mathrm{NO}_{2}$ primary standard for 1 hour $\left(320 \mu \mathrm{g} \mathrm{m}^{-3}\right.$ or $\left.170 \mathrm{ppb}\right)$, showing that NOx emissions are not a critical problem in this area.
The ozone concentrations show a maximum between midday and approximately 3:00 pm, characteristic of secondary pollutants. When compared to the values obtained at the Presidente Vargas Avenue, in either winter or summer, it can be observed that at FIOCRUZ Campus the concentrations are larger and the maximum is reached earlier. The maximum values measured in this work are between 20 and $50 \mathrm{ppb}$, depending on the month, while in downtown maximum values, obtained in 2003, were between 1.70-10.66 $\mathrm{ppb}^{2}$ There are no available data for Presidente Vargas Avenue, in 2002, since all archives of FEEMA were destroyed by fire. The months with higher concentrations were April, May and June, which also differ from the data, obtained in the downtown area, where the larger values are reached in the summer (December). Maximum ozone concentration is lower than the national standard, 80 ppb. ${ }^{29}$ Higher concentrations of ozone were expected during the summer and spring. The result may be explained, as detailed bellow, because in this area, the consumption of ozone by NO controls ozone levels. In summer, the photochemical dissociation of $\mathrm{NO}_{2}$ to $\mathrm{NO}$ is faster while the photochemical ozone formation and consumption are both increased and the VOC photoxidation is not the determinant step of the reaction mechanism. 


\section{Simulated results}

A model was constructed for simulating the concentrations of secondary pollutant, particularly ozone, at the studied location. August 2002 was selected as the month model because of its intermediate values for ozone.

Figures $2 \mathrm{a}$ and $2 \mathrm{~b}$ show the experimental and calculated hourly averages for $\mathrm{CO}$ and $\mathrm{O}_{3}$, respectively. The two sets of values are found to be in reasonable agreement for such a simple model. The more pronounced differences are observed in the afternoon.
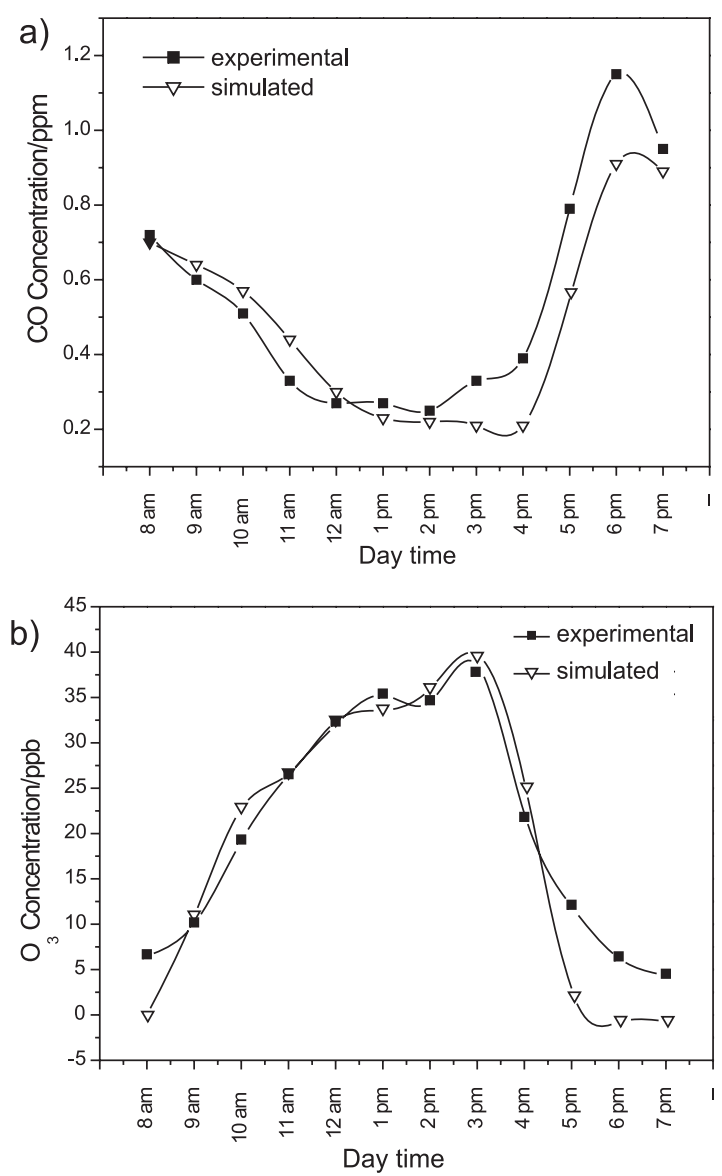

Figure 2. Calculated $\mathrm{CO}(2 \mathrm{a})$ and $\mathrm{O}_{3}(2 \mathrm{~b})$ time profile for the base case and average experimental values for August 2002, obtained by the Automatic Mobile Monitoring Station at FIOCRUZ Campus.

The maximum experimental value for ozone was 38.5 $\mathrm{ppb}$ at 3:00 pm, while the value obtained through the simulation was $39.8 \mathrm{ppb}$ at 3:00 pm, the difference being only $9.7 \%$. The difference for $\mathrm{CO}$ is smaller or equal to $20 \%$, depending on the time of the day.

These results indicate that the constructed scenario is representative of the average air quality at the studied location, in August.

In Figure 3, the ozone isopleths are displayed. The main characteristic of these results is that the modeled scenario is located in the lower area of the diagram, which corresponds to high $\mathrm{VOC} / \mathrm{NO}_{\mathrm{x}}$ ratio (16.7). This region is typical of suburban, rural and downwind areas. In this case, the chemistry of polluted air masses is $\mathrm{NO}_{\mathrm{x}}$-limited and $\mathrm{NO}_{\mathrm{x}}$ control is most effective. ${ }^{1}$

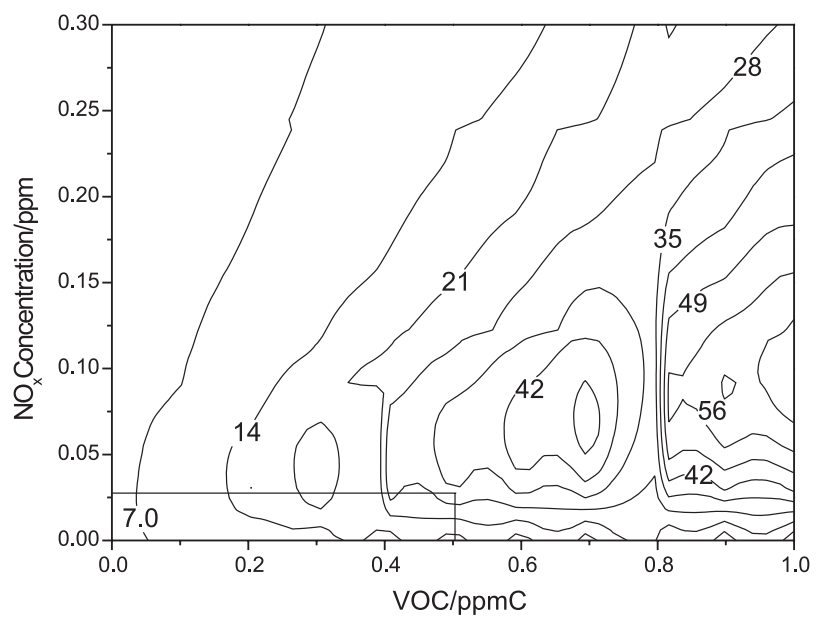

Figure 3. Ozone isopleth diagram calculated for the base case.

In contrast, the simulations done for Presidente Vargas Avenue showed that locations in downtown, with a high vehicular traffic density, are associated with the upper region of the figure, which correspond to a low $\mathrm{VOC} / \mathrm{NO}_{\mathrm{x}}$ ratio (2.5). Low $\mathrm{VOC} / \mathrm{NO}_{\mathrm{x}}$ have been found to be typical of polluted air masses found in many major urban centers. In this case, the system is VOC-limited and reducing VOC results in an ozone decreasing. However, reducing $\mathrm{NO}_{\mathrm{x}}$, at constant VOC, actually leads to increase in ozone.

This can be better understood by examining the mechanism of ozone reactions in the urban atmosphere. Ozone is formed through a series of reactions that can be summarized as follows:

$\mathrm{VOC}+\mathrm{OH} \rightarrow \rightarrow \rightarrow \mathrm{HO}_{2}+$ radicals

$\mathrm{HO}_{2}+\mathrm{NO} \rightarrow \mathrm{NO}_{2}+\mathrm{OH}$

$\mathrm{HO}+\mathrm{NO}_{2}+\mathrm{M} \rightarrow \mathrm{HNO}_{3}+\mathrm{M}$

$\mathrm{NO}_{2}+\mathrm{hv} \rightarrow \mathrm{O}\left({ }^{3} \mathrm{P}\right)+\mathrm{NO}$

$\mathrm{O}\left({ }^{3} \mathrm{P}\right)+\mathrm{O}_{2} \rightarrow \mathrm{O}_{3}$

Radicals $\rightarrow \rightarrow \rightarrow$ aldehydes $+\mathrm{H}_{2} \mathrm{O}+\mathrm{CO}$

Ozone is consumed by the following reactions:

$\mathrm{O}_{3}+\mathrm{hv} \rightarrow \mathrm{O}\left({ }^{3} \mathrm{P}\right)+\mathrm{O}_{2}$ 
$\mathrm{O}_{3}+\mathrm{NO} \rightarrow \mathrm{O}_{2}+\mathrm{NO}_{2}$

$\mathrm{O}_{3}+$ alkenes $\rightarrow$ products

The hydroxyl radical is the key reactive species in the chemistry of ozone formation. The VOC-OH reaction initiates the oxidation sequence. There is a competition between $\mathrm{VOC}$ and $\mathrm{NO}_{\mathrm{x}}$ for the $\mathrm{OH}$ radical (reactions 1 and 3). At a high $\mathrm{VOC} / \mathrm{NOx}$ ratio, $\mathrm{OH}$ will react mainly with VOC and consumption of ozone by $\mathrm{NO}_{x}$ will control ozone levels. At low $\mathrm{VOC} / \mathrm{NO}_{\mathrm{x}}$ ratio the $\mathrm{NO}_{\mathrm{x}}$ reaction with $\mathrm{OH}$ can predominate. Also, the reaction of ozone with $\mathrm{NO}$ (reaction 8 ) is fast, so that ozone is effectively titrated by high NO concentrations. ${ }^{1,30}$

For a $\mathrm{VOC} / \mathrm{NO}_{\mathrm{x}}$ ratio of approximately 5.5 the rates of reaction of VOC and $\mathrm{NO}_{2}$ with $\mathrm{OH}$ are equal. If the $\mathrm{VOC} / \mathrm{NO}_{\mathrm{x}}$ ratio is less than 5.5, reaction of $\mathrm{OH}$ with $\mathrm{NO}_{2}$ (reaction 3) predominates, and removes $\mathrm{OH}$ radicals from the active VOC oxidation cycle, retarding the further production of ozone. When $\mathrm{VOC} / \mathrm{NO}_{\mathrm{x}}$ ratio exceeds the value 5.5, $\mathrm{OH}$ reacts accelerating ozone production. ${ }^{30}$

The city's downtown area has high NO concentrations making the ozone consumption the predominant reactions. On the other side, in the suburbs the reactions of ozone formation are the predominant ones, causing higher ozone concentrations.

In spite of being very simple, the model explain the main characteristics of the studied region and show why suburban areas in Rio de Janeiro have higher $\mathrm{O}_{3}$ concentrations than downtown areas.

\section{Conclusions}

In this work an integrated study of the air quality of a suburban industrial-residential area in Rio de Janeiro is presented. Aldehydes concentrations are high in comparison with literature data and may be due to industrial input and to the lack of chemical treatment of effluents and solid waste. In contrast BTEX concentrations are similar to those determined in downtown Rio de Janeiro. In general, the air quality of the area is considered as moderated by the environmental regulatory agency FEEMA, since $\mathrm{PM}_{10}$ levels are currently high in comparison with national standards.

Simulated results are in good agreement with experimental data. The maximum calculated value for ozone concentration was $39.8 \mathrm{ppb}$ at 3:00 pm, the difference with the experimental value being only $9.7 \%$. The calculated ozone isopleths show that ozone concentrations are higher than those determined in downtown because the local has a high $\mathrm{VOC} / \mathrm{NO}_{\mathrm{x}}$ ratio (16.7) and ozone formation is controlled by $\mathrm{NO}_{x}$.

\section{Acknowledgments}

This work was sponsored by CNPq, FAPERJ and CAPES. We thank the Environmental Municipal Department for permission to collect the samples at the monitoring station and use the date of automatic criteria pollutants monitors.

\section{References}

1. Finlayson-Pitts, B. J; Pitts, J. N. Jr.; Chemistry of the upper and lower Atmosphere: Theory, Experiments and Applications, Academic Press: Florida, 2000.

2. http://www.feema.rj.gov.br, accessed in July 2005.

3. Tanner, R.L.; Miguel, A.H; de Andrade, J.B.; Gaffney, J.S.; Streit, G.E.; Environ. Sci. Technol.. 1988, 22, 1026.

4. Miguel, A. H.; Environ. Sci. Technol.. 1991, 25, 590.

5. Corrêa, S.M.; Arbilla, G.; Atmos. Environ.. 2005, 39, 4513.

6. Martins, E.M.; Arbilla, G.; Bauerfeldt, G.F.; De Paula, M.; Chemosphere 2007, 67, 2096.

7. Corrêa, S.M.; Ph.D. Thesis, Universidade Federal do Rio de Janeiro, Brazil, 2003.

8. Corrêa, S.M.; Martins, E.M.; Arbilla, G.; Atmos. Environ. 2003, $37,23$.

9. Martins, E.M.; Ph.D. Thesis, Universidade Federal do Rio de Janeiro, Brazil, 2005.

10. http://www.rio.rj.gov.br/smac/, accessed in March 2005.

11. Arbilla, G.; De Oliveira, K. M. P. G.; Quim. Nova 1999, 22, 790.

12. Arbilla, G.; Martins, E. M.; Moreira A.; Moreira, L. F. R.; J. Braz. Chem. Soc. 2002, 13, 308 .

13. Martins, E. M.; Arbilla, G.; Atmos. Environ. 2003, 37, 1717.

14. US-EPA; Compendium Method TO-11A. Cincinnati, OH: U.S. Environmental 1997.

15. US-EPA;. Compendium Method TO-1, Cincinnati, OH: U.S. Environmental 1998.

16. US-EPA; Compendium Method TO-2 Cincinnati, OH: U.S. Environmental 1998.

17. Gery, M.W.; Crouse, R.R.; US-EPA, NC, EPA-9D2196 NASA, 1990.

18. http://master.iag.usp.br/, accessed in November 2002.

19. Campos, I. C. B.; Pimentel, A. S.; Corrêa, S. M.; Arbilla, G.; J. Braz. Chem. Soc. 1999, 10, 203.

20. Carter, W.P.L.; Atmos. Environ. 1990, 24A, 481.

21. De Andrade, J.B.; Andrade, M.V.; Pinheiro, H.L.C.; J. Braz. Chem. Soc. 1998, 9, 219.

22. De Andrade, J.B.; Andrade, M.V.; Pinheiro, H.L.C.; Pereira, P.A.P.; Quim. Nova 2002, 25, 1117. 
23. Kuwata, K.; Uebori, M.; Yamasaki, H.; Kuge,Y.; J. Chromatogr. Sci. 1979, 17, 264.

24. Gaffney, J.S.; Marley, N.A.; Martin, R.S.; Dixon, R.W.; Reyes, L.G.; Popp, C.J.; Environ. Sci. Technol. 1997, 31, 3053.

25. Guicherit, R.; Schulting, F.L.; Sci. Total Environ. 1985, 43, 193.

26. Grosjean, D.; Miguel, A.H.; Tavares, T.; Atmos. Environ.. 1990, 24b, 101.

27. Kuwata, K.; Uebori, M.; Yamasaki, H; Kuge, Y.; Kiso, Y.; Anal. Chem. 1983, 55, 2013.
28. Grosjean, D.; Environ. Sci. Technol. 1982, 16, 254.

29. http://www.mma.gov.br/port/conama/res/res90/res0390.html, accessed in May 2005.

30. Seinfield, J. H.; Atmospheric Chemistry and Physics of Air Pollution, John Willey \& Sons: Chichester, 1986.

Received: April 27, 2006

Web Release Date: March 9, 2007

FAPESP helped in meeting the publication costs of this article. 